\title{
Seasonal variation in food and feeding habit of Indian major carp (Labeo rohita Ham.1822) in Vallabhsagar reservoir, Gujarat
}

\author{
Nandita Soni* and N. C. Ujjania \\ Department of Aquatic Biology, Veer Narmad South Gujarat University, Surat-395007 (Gujarat), INDIA \\ *Corresponding author. E-mail: nanditasoni17@yahoo.in \\ Received: July 22, 2016; Revised received: January 25, 2017; Accepted: April 26, 2017
}

\begin{abstract}
The gut content analysis provides the information on food components and feeding habit of fish which is an important aspect for fisheries management. In present study, the qualitative and quantitative analysis of gut content of Indian major carp rohu (Labeo rohita Ham. 1822) from Vallabhsagar reservoir (Gujarat), were conducted during June 2013 to May 2014. The results on gut content shows that qualitative changes in food component were not found but quantitative changes were observed during the study period. In the gut of fish, food contents i.e. phytoplankton $(32.52 \%)$, plant materials $(25.07 \%)$, Insects $(13.39 \%)$, decay matter $(13.39 \%)$ and zooplankton $(11.42$ $\%)$ were observed. The quantitative changes of food contents were also verified by the analysis of gasrosomatic index (GaSI) and it was maximum (5.582 \pm 0.106$)$ during post breeding season and minimum $(3.589 \pm 0.150)$ during breeding season as fish feeds voraciously to compensate the energy loss due to sexual maturity. On the basis of these results, it was concluded that studied fish (rohu) was herbivorous and mainly fed on phytoplankton and plant materials.
\end{abstract}

Keywords: Food and feeding, Gastrosomatic index, Gut analysis, Herbivorous, Labeo rohita

\section{INTRODUCTION}

Rohu (Labeo rohita) is one of the most preferred and rapid growing fish among the Indian major carps and it is accepted as a potential aquaculture species in different parts of the world including India, Pakistan, Bangladesh, Myanmar and other southern Asian countries. The magnitude of fish population in a region is the function of food potentialities and varies with the species, season, availability, food item preference, maturity stage and spawning season of the fish (Krishna et al., 2016). Fish performs their various physiological activities such as growth, reproduction, restoration etc. with the help of energy obtained from the food and are highly adopted in their feeding habits with utilizing most of the readily available food components. The qualitative and quantitative dietary analysis of fish in their natural habitats enhances the understanding of the growth, abundance, productivity of water body (Nansimole et al., 2014) and used to describe food habits, feeding patterns of fishes (Ekpo et al., 2014). The feeding intensity of mature fish decreases during the spawning season, as compared to the non-spawning season (Ujjania, 2003). The relationship between the fish and food component is essential for the production and exploitation of the fish stocks (Panicker, 2000). The food and feeding habit of Oreochromis mossambicus (Peters) in relation to seasonal changes in a small pond of upper Assam is described by Hatikakoty and Biswas (2003). Ujjania (2003) studied the gastrosomatic index of Indian Major Carp in three different water bodies of southern Rajasthan. Euphrasia (2004) reported the food and feeding habits of Osteobrama bakeri and Manoj kumar (2006) studied the feeding habits of Puntius carnaticus from Kerala. Padmakumar et al. (2009) elaborated the food and feeding behavior of golden catfish in water body of Gunther. Shalloof and Khalifa (2009) reported about stomach contents and feeding habit of Oreochromis niloticus from Abu-Zabal lakes, Egypt and Omondi et al. (2013) studied the food and feeding habit of three freshwater fishes of Baringo lake, Kenya. Information regarding food and feeding habit is basic criteria for its reproduction and farming management. Thus, the present study was conducted to gather the information on quality, quantity of food contents and feeding habit of rohu (L. rohita) in large reservoir with reference to seasonal variation and it would be helpful to prepare the management strategy and policies for sustainable management of reservoir fishery.

\section{MATERIALS AND METHODS}

Total 58 specimens of Labeo rohita were randomly collected during June 2013 to May 2014 from commercial landing centers (Serula, Ukai, Chacharbunda, Thuthi, Jamli and parchuli) of Vallabhsagar reservoir which is situated on river Tapi at $21^{\circ} 15^{\prime} \mathrm{N}$ Latitude and $73^{\circ} 35^{\prime}$ E Longitude geographical location (Fig. 1). 


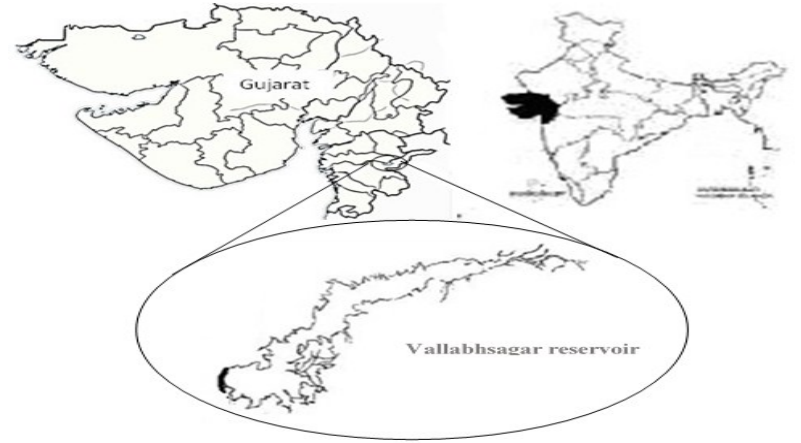

Fig. 1. Map of the study area (Vallabhsagar reservoir).

The fish can easily identify with conspicuously arched head silver body, cycloid scale and 12-13 dorsal fin rays (Day 1869). Each specimen was weighed to the nearest $1.0 \mathrm{gm}$ with the help of top loading single pan balance (Sartorius 'PT' 600) and dissect the fish to collect gut. Weight of gut was measured and its contents were preserved in $4 \%$ formalin solution and bring at Research laboratory, Department of Aquatic Biology, Veer Narmad South Gujarat University, Surat for further analysis. The gut contents were analyzed with the help of Trinocular microscope (Olympus $\mathrm{CH}$ 20i) to follow the frequency occurrence methods of Hynes (1950) and Pillay (1952) and grouped in zooplankton, phytoplankton, plant material, insects and decay matter.

Gastrosomatic Index (GaSI) for each month was obtained through the equation (1) of Desai (1970). For data compilation and calculation software PAST 1.021 was used.

$\mathrm{GaSI}=$ Weight of the gut/Total weight of the fish) $\times 100$
Table 1. Gastrosomatic index of Labeo rohita in Vallabhsagar reservoir.

\begin{tabular}{llll}
\hline Seasons & Minimum & Maximum & Mean \pm SE \\
\hline Monsoon & 2.506 & 5.783 & $3.589 \pm 0.150$ \\
Post-Monsoon & 4.063 & 7.385 & $5.582 \pm 0.106$ \\
Pre-Monsoon & 2.781 & 7.195 & $4.569 \pm 0.429$ \\
Pooled & 2.506 & 7.385 & $4.587 \pm 0.159$ \\
\hline
\end{tabular}

\section{RESULTS AND DISCUSSION}

The result of the study is elaborated in the table 1 and figure 2 (A, B, C and D). The results shows that dominancy of gut contents, Phytoplankton (34\%) >Plant material $(24 \%)>$ Decay matter $(15 \%)>$ Insects $(14$ $\%)>$ Zooplankton (13\%) during monsoon, Phytoplankton $(37 \%)>$ Plant material $(18 \%)>$ Decay matter $(16 \%)>$ Insects $(15 \%)>$ Zooplankton $(14 \%)$ during post monsoon and Plant material $(40 \%)>$ Phytoplankton $(29 \%)>$ Insects $(13 \%)>$ Decay matter $(10$ $\%)>$ Zooplankton (8\%) during pre-monsoon season were observed whereas it was Phytoplankton (34\%) $>$ Plant material $(26 \%)>$ Decay matter $(14 \%)>$ Insects $(14 \%)>$ Zooplankton $(12 \%)$ during the study period (Fig. 2, A, B, C and D). Results shows that qualitative changes in different season was not observed whereas gut contents were dominated by phytoplankton and plant materials which indicate that studied fish species is herbivores. It may be due to food preference and availability of different food contents in water body. Alikunhi (1952) reported Labeo rohita as plankton feeder from sub-tropical water bodies and Ravindranathan (2003) documented the major food content of the L. rohita specifying it as herbivorous fish. Kumar et al. (2007) assigned the L. rohita as plankton feeder.


Fig. 2. Seasonal variations in gut contents of Labeo rohita in Vallabhsagra reservoir(A-Monsoon, B- Post monsoon, C-Pre monsoon and D-Pooled). 


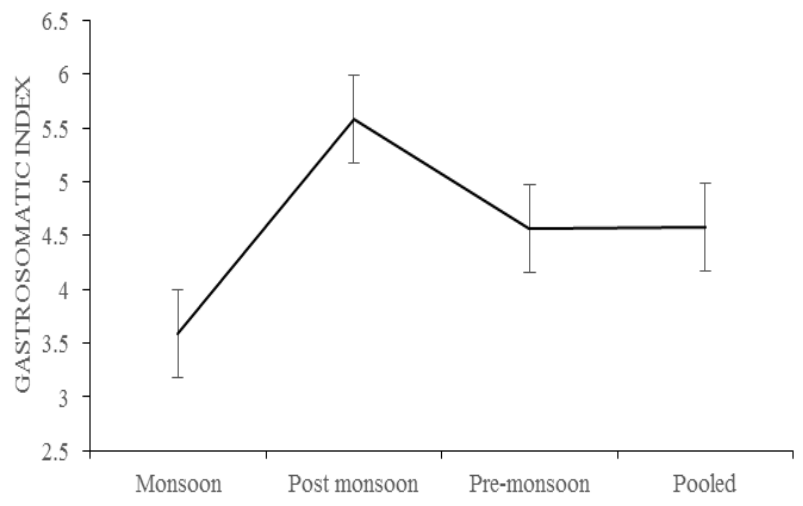

Fig. 3. Seasonal variation in gastrosomatic index of Labeo rohita in Vallabhsagra reservoir.

Manon and Hossain (2011) studied the food and feeding habit of Cyprinus carpio from Nawgao Bangladesh and reported the studied fish as herbivores. Khabade (2015) and Maheshwari (2015) analyzed the gut contents of rohu from Siddhewadi lake of Sangli and Singanallurlake, Combatore, Tamil Nadu, respectively and reported that rohu is herbivorous fish. Similarly, Rajanna et al. (2015) also reported that Labeo fimbratus from Vanivalas Sagar of Karnataka was herbivorous.

Quantitative variation in food contends during the study was observed and verified by the analysis of gastrosomatic index. It was minimum $(3.932 \pm 0.2)$ during the breeding season and maximum $(5.378 \pm 0.2)$ during the post breeding season whereas annual mean of it was $4.537 \pm 0.159$ (Table 1 and Fig. 3). Result depict that during spawning season, feeding rate decreases and increases immediately after spawning as the fish feeds voraciously to compensate the energy loss during the breeding (monsoon season). Similar observation was documented by Rao et al. (1998) on channa species from East Godavari district (A.P.), Hatikakoty and Biswas (2003) on Tilapia from subtropical water body and by Kumar et al. (2015) on Catla from Udai Sagar Rajasthan. Similarly, Sarkar and Deepak (2009) studied the gastrosomatic index value of Chitala chitala and reported it maximum during pre-monsoon and minimum during monsoon season.

\section{Conclusion}

The seasonal changes in quality of food contents was not observed but gut contents were dominated by phytoplankton and plant material which indicates that fish is herbivorous. Seasonal changes in quantity of gut content was observed and it is confirmed by the determination of gastrosomatic index (GaSI). The value of GaSI was minimum during breeding season and maximum during post breeding which inferred that fishes utilize their energy for gonadal development and maximum value indicates availability of sufficient food and intensive feeding after breeding season.

\section{REFERENCES}

Alikunhi, K. H. (1952). On the food of young carp fry. J. Zoo. Soc. India, 4:77-84

Desai, V. R. (1970). Studies on the fishery and biology of Tor tor (Ham.) from river Narbada. J. Inland Fish. Soc., India.,2: 101-112

Day, F. (1869). On the fisheries of Orissa, Pt.II, Pro. Zool.Soc. Lond., pp. 372-387

Euphrasia, C. J. and Kurup, B. M. (2008). Maturation and spawning of Osteobrama bakeri- a threatened endemic ornamental fish in Kerala, India. Indian J. Fish.,55(3): 273-280

Hatikakoty, G. and Biswas, S. P. (2003). Food and feeding habits of Oreochromis mossambicus (Peters) from a subtropical environment. J. Inland Fish. Soc. India., 35 (2):57-61

Hynes, H. B. N. (1950). The food of fresh water stickle backs (Gasterosteus aculeatus) and Pygosteus pungitius with review of the methods used in the studies of the food of fishes. J. Animal Ecol., 19(1): 35-38

Ekpo, I. E., Mandu A., Essien-Ibok and Joseph N. Nkwoji. (2014). Food and feeding habits and condition factor of fish species in Qua Iboe River estuary, Akwa Ibom State, Southeastern Nigeria. Int. J. Fish. Aquatic Studies, 2(2): 38-46

Khabade, S.A. (2015). Study of gut contents of major carps for their food habits from Sidddhewadi lake of Tasgaon tahsil of Sangli district Maharashtra. Int. J. Fish. \& Aquatic Studies, 2(4S): 1-4

Kumar, L., Sharma B. K, Sharma S. K, Upadhyay B. and Mishra V. (2015). Food and Feeding Habits of Catla Catla (Hamilton) From Lake Udai Sagar, Udaipur. Int. J. Fauna \& Biol. Studies, 2(5): 06-08

Krishna P. V., Panchakshari V. and Prabhavathi, K. (2016). Feeding Habits and Stomach Contents of Asian seabass Lates calcarifer from Nizampatnam Coast, International Journal of Advanced Research (2016), Volume 4, Issue 4, 168-172

Manon, M. R. and Hossain, M. D. (2011). Food and feeding habit of Cyprinus carpio Var. Specularis. J. Sci. Found., 9(1\&2): 163-181

Manoj kumar, T. G. (2006). Fish habitats and species assemblage in the selected rivers of Kerala and Investigation on life history traits of Puntius carnaticus (Jerdon, 184), Thesis submitted to Cochin University of Science \& Technology, Cohin (Kerala).

Maheshwari, U. M. (2015). An Emphirical Study of gut contents of major carps for their food habits from Singanallur lake of Coimbatore District, Tamil Nadu. Biotechnology, 4(8): 240-241

Nansimole, A., Sruthi., Gayathri, T. V., Lekshmi, S., Balasubramaniam, N. K. and Radhakrishnan. (2014). Studies on morphometry feeding biology and sex ratio of Saurida undosquamis (Richardson, 1884) from Neendakara area, Kollam, south west coast of India. Indian J. Sci. Res., 5(2): 51-58

Omondi, R., Yasindi A. W. and Magana A. M. (2013). Food and feeding habits of three main fish species in Lake Baringo, Kenya, Academic journal., 5(9): 224-230 
Padmakumar K. G., Bindhu, L., Sreerekha, P. S. and Joseph, N. (2009). Food and feeding behavior of the golden catfish, Horabagrus brachysoma (Gunther). Indian J. Fish., 56(2): 139-142

Panicker, A. C. (2000). Ecological impact of tilapia, Oreochromis mossambicus (Peters) on the indigenous fish species in two reservoirs of Kerala. Ph.D. Thesis, University of Kerala, Trivandrum, India.

Pillay, T. V. R. (1952). A critique of the methods of study of food of fishes. J. Zoo. Soc., India, 4: 185-200

Kumar, R., Sharma, B. K. and Sharma, L. L. (2007). Food and feeding habit of Catla catla (Hamilton-Buchanan) from Daya reservoir, Udaipur, Rajasthan. Indian $J$. Anim. Res., 41 (4): 266-269

Rajanna, K. B., Anjaneyappa H. N., Benakappa S., Chethan N., Reddy H. R. V., Somashekar., Prabhudeva K.N., Basavaraju Y. and Muttappa, K. (2015). Food and feeding habits of fringe Lipped Carp, Labeo fimbriatus
(Bloch) of the Vanivilas Sagar Reservoir of Karnataka. Int. J. Rec. Sci. Res., 6(4) :3431-3434

Rao, L. M., Ramaneswari K. and Rao, L.V. (1998). Food and feeding habits of Channa species from East Godavari district (Andhra Pradesh). Indian J Fish., 45(3):349-353

Ravindranathan, K. R. (2003). Economic zoology, Dominant Publishers and Distributors, New Delhi Pp 323-328

Sarkar, U. K and Deepak P. K. (2009). The diet of clown knife fish Chitala chitala (Hamilton- Buchanan) an endangered notopterid from different wild population. $E$ -J. Icht., 1: 11-20

Shalloof K. A. S. and Khalifa, N. (2009). Stomach contents and feeding habits of Oreochromis niloticus (L.) from Abu-Zabal lakes, Egypt. World Appl. Sci. J., 6(1): 1-5

Ujjania, N. C. (2003). Comparative performance of Indian major carps (Catla catla, Labeo rohita and Cirrhinus mrigala) Ph.D. Thesis. Central Institute of Fisheries Education (ICAR) Mumbai. 